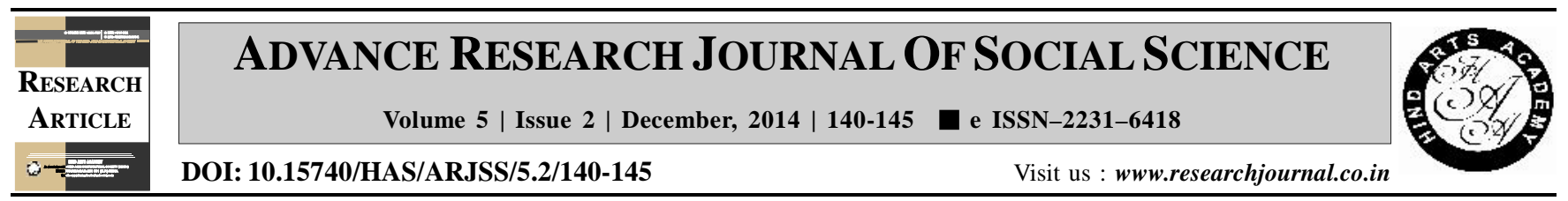

\title{
Profilistic study of self-help group in Dharwad district
}

Shobha Nagnur*, Veena Chandavari, Vijayalaxmi Pawar and Rekha Rayanagoudar

Department of Home Science Extension, College of Rural Home Science, University of Agricultural Sciences, DHARWAD (KARNATAKA) INDIA

(Email: shobha_nagnur@yahoo.com)

\section{ARTICLE INFO :}

$\begin{array}{lll}\text { Received } & : & 17.06 .2014 \\ \text { Revised } & : & 26.10 .2014 \\ \text { Accepted } & : & 08.11 .2014\end{array}$

\section{KEY WORDS :}

SHG, Income generation, Profilistic study HOW TO CITE THIS ARTICLE :

Nagnur, Shobha, Chandavari, Veena, Pawar, Vijayalaxmi and Rayanagoudar, Rekha (2014). Profilistic study of self-help group in Dharwad district. Adv. Res. J. Soc. Sci., 5 (2) : 140-145.

*Author for correspondence

\begin{abstract}
The research study was conducted to know the overall status of SHGs in Karnataka and specifically that of Dharwad district during the year 2014-15. In Karnataka, the maximum number of SHGs i.e. 23038 was seen Tumkur while next in order was Belgaum 16952. The least were in Kodagu district (2279) and Dharwad district has 7761 SHGs. Four villages from Dharwad taluka were purposively selected for the study based on the highest number of registered SHGs. Only those SHGs registered (2011 official records of District Rural Development Agency) during 2008-09 were selected for the study. The findings revealed that only 03.12 per cent of SHGs had discontinued while 52.83 per cent were involved in some entrepreneurial activity. A sizable number (44.02\%) of SHGs were in money saving and lending only. Individual income generation activities were more popular than group income generation. Popular activities were tailoring, Agarbatti and candle making and trading.
\end{abstract}

